Original article

\title{
A comparison of local and general models of leaf area and biomass of urban trees in USA
}

\author{
Nilesh Timilsina*, Jackson L. Beck, Megan S. Eames, Richard Hauer, Les Werner \\ College of Natural Resources, University Wisconsin-Stevens Point, United States
}

\section{A R T I C L E I N F O}

\section{Keywords:}

Allometric equation

i-Tree

Leaf area

Leaf biomass

Urban

\begin{abstract}
A B S T R A C T
Ecosystem service estimation is a very popular topic. Many urban studies use the i-Tree Eco model developed by US Forest Service to estimate ecosystem services. Several ecosystem service estimation studies have been conducted acting upon the assumption that relationships developed elsewhere are applicable to sites that vary in species, site, climate, and environmental conditions. This study tested the accuracy of highly used existing leaf area and biomass models when used outside the region in which it was developed. To do this, we measured 74 urban trees from five species in Stevens Point, Wisconsin collecting data such as diameter at breast height (Dbh), tree height, height to the base of live crown, crown width, crown volume, leaf area, and leaf dry weight biomass. Using the data, we developed two models each to predict leaf area and biomass. Using ten independent samples, we compared our predictions with predictions from the existing models which are also used in i-Tree. Our results indicated that the local models developed in the current study predicted leaf area and biomass better than existing models which had higher prediction error. The difference in prediction will ultimately affect ecosystem services estimation when. using i-Tree, and future studies should acknowledge the difference.
\end{abstract}

\section{Introduction}

Over half of the world's population currently inhabits cities (United Nations, 2010). By the year 2030 urban areas are projected to increase world wide by 1.2 million $\mathrm{km}^{2}$ annually (Seto et al., 2012). It is expected that $60 \%$ of the world's population will also live in cities by 2030 (Rydin et al., 2012). Within the United States of America, urban areas are projected to increase from $3.1 \%$ in 2000 to $8.1 \%$ in 2050 , which would result in the urbanization of $118,300 \mathrm{~km}^{2}$ of forestland (Nowak and Walton, 2005). The increase in urbanization and urban population intensified the importance of urban vegetation and forests to provide ecosystem services such as carbon sequestration, air pollution removal, maintenance of water quality, and many other social benefits (Dwyer et al., 1992; Wolf, 2003; Nowak and Dwyer, 2007; Miller et al., 2015). As the development of urban areas continues, it becomes increasingly important to accurately quantify the services and values that urban trees provide (Nowak and Dwyer, 2007; Seto et al., 2012; McHale et al., 2009).

Several studies have demonstrated and quantified the urban forest ecosystem services, and estimated their total monetary benefits to society (Escobedo et al., 2010; Zhao et al., 2010; Russo et al., 2014). Most of these studies used the i-Tree Ecomodel developed by US Forest
Service to quantify and value the urban forest ecosystem services. There are 36,000 registered i-Tree users from 120 countries (Nowak, 2015).

The allometric relationship (e.g., tree diameter and crown diameter, diameter and aboveground biomass, diameter and crown height) of trees is well established and useful to predict the size of one part based on another that is easier to collect (McHale et al., 2009). Several studies that estimate urban tree biomass and carbon dynamics assume that the biomass equations developed elsewhere are applicable to sites that vary in species, climate, and environmental conditions (Nowak and Crane, 2002; Timilsina et al., 2014). Although i-Tree has been adapted in some countries such as UK and Australia (https://www.itreetools.org/eco/ international.php, accessed Sep 10, 2016), several other studies using the i-Tree model outside the specific study areas where this predictive model was developed assume that the allometric relationships and predictive equations used therein are applicable to other ecosystems, regions, and species. For example, equations to predict leaf area (using tree diameter and crown dimensions) of individual trees within i-Tree were developed using urban tree data collected in Chicago, Illinois (Nowak, 1996). Predicted leaf biomass and leaf area estimates are further used in calculating air pollution removal, emission of volatile organic compounds (VOC), and shading effects (Nowak et al., 2008). Within i-Tree, standardized VOC emissions are calculated by multi-

\footnotetext{
* Corresponding author.

E-mail addresses: ntimilsi@uwsp.edu (N. Timilsina), Jackson.L.Beck@uwsp.edu (J.L. Beck), Megan.S.Eames@uwsp.edu (M.S. Eames), Richard.Hauer@uwsp.edu (R. Hauer), Les.Werner@uwsp.edu (L. Werner).
} 
plying species leaf biomass by a genus-specific emission factor. Similarly, leaf area data is used in estimating air pollution removal rates (Nowak et al., 2008). Therefore, leaf area and biomass are considered one of the key variables in estimating ecosystems services in i-Tree (Nowak et al., 2008).

The allometric relationships used to predict tree height and crown information may change according to site, climatic and environmental conditions (Pallardy, 2008; Lines et al., 2012; Rust, 2013). For example, allometric relations between the aforementioned variables can be affected by tree growth rate. In urban landscapes the rate of tree growth is highly variable owing to differences in landuse, management objectives, and cultural practices (e.g. nutrient management and irrigation; Rhoades and Stipes, 1999; Scharenbroch and Catania, 2012). Variables that affect urban tree growth such as amount of nutrients in the soil, soil moisture, relative humidity, vapor pressure deficit, length of growing season etc. change from one city to another (Close et al., 1996a,b; McHale et al., 2009). Therefore, assumptions of similar relationships between tree size and crown information might introduce an error in estimates of ecosystem services when the i-Tree model is used outside the data range used in the model development.

This work will examine the difference in estimation of leaf area and biomass using locally developed versus general equations from a disparate site and will provide information to managers and researchers about the relative accuracy of assuming consistent allometric relationships among different cities and regions. Although studies have emphasized the differences of using biomass equations developed in forest in predicting urban trees biomass (McHale et al., 2009; Timilsina et al., 2014), studies comparing model predictions of leaf area and biomass using equations developed for specific cities are rare. Peper and McPherson (2003) compared only leaf area estimation using four different methods and reported the logarithmic equation from Nowak (1996) overestimated leaf area. McHale et al. (2009) found a range of variability in biomass estimation (sometimes more than $300 \%$ at an individual tree level) using allometric biomass equations developed using forest trees vs locally developed urban tree equations. Similarly, Timilsina et al. (2014) found that generalized models in i-Tree over predicted biomass of oak trees compared to locally developed models in Gainesville, Florida. Some of these studies highlight the importance of using localized biomass equations to accurately estimate the ecosystems services.

In the current study, we used an approach similar to that of Nowak (1996) to develop equations to predict urban tree leaf area and leaf biomass using data obtained from trees in Stevens Point, WI and compared the predictions from our model to those of Nowak (1996). We hypothesize that a locally developed model using data from Stevens Point would adequately predict leaf area and biomass than a general model of Nowak (1996). We also intend to find out whether the magnitude of difference between the models is large enough to warrant the development and use of local models. Results from this study will encourage future work in developing a greater set of local equations for the i-Tree model to estimate and value ecosystem services, reveal errors introduced by using generalized equations, and contribute to improving the accuracy of ecosystem service estimation and valuation.

\section{Materials and methods}

The current study was conducted in Stevens Point WI, USA (Longitude: -89.5855 , Latitude: 44.5113 ), which is slightly cooler and slightly drier than Chicago IL, USA (Longitude: -87.9336, Latitude: 41.995) based on 1981-2010 U.S. climatological weather data. Stevens Point receives $830 \mathrm{~mm}$ of precipitation annually compared to $937 \mathrm{~mm}$ annually in Chicago. The mean annual high temperature is $15^{\circ} \mathrm{C}$ in Chicago and $12{ }^{\circ} \mathrm{C}$ in Stevens Point (Fig. 1).

A total of 74 trees representing five species (similar to Nowak, 1996) were randomly selected from the city of Stevens Point street tree database (Table 1). All trees were open grown and displayed excellent

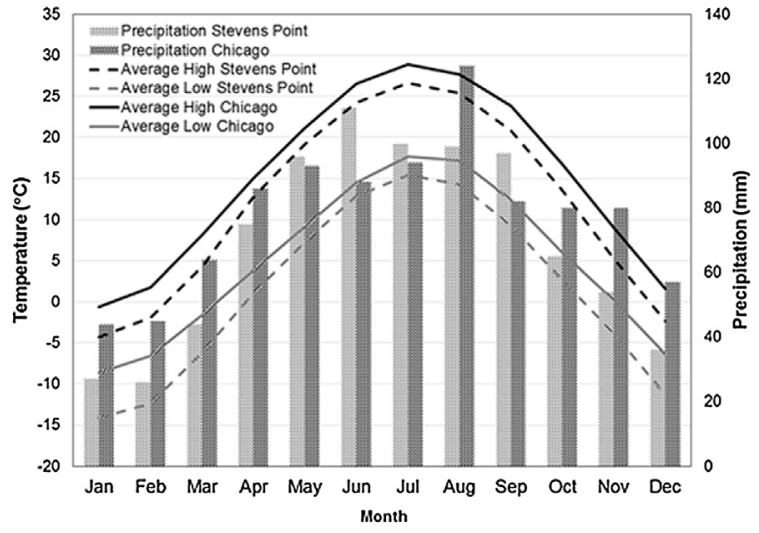

Fig. 1. Annual precipitation and average high and low temperature in Stevens Point, WI and Chicago, Il.

crown condition. To the best extent possible, trees within a species represented a spectrum of diameter class sizes from small to large. This sampling design was consistent with Nowak (1996).

For each tree, we collected data on diameter at breast height (Dbh, $\mathrm{cm})$ at $1.37 \mathrm{~m}$, tree height $(\mathrm{m})$, height to the base of live crown (m), and average crown diameter $(\mathrm{m})$. Crown diameter was collected at the longest part of the crown and second measurement was made perpendicular to the first measurement. Average crown diameter calculated from the two measurements was used in the model fitting process.

Total crown volume was calculated by summing the volume of the crown at $1.5 \mathrm{~m}$ increments (Nowak, 1996; Fig. 2.). Volume of the increments was determined by summing the volume of eight pies using the radius of crown canopy at $0,45,90,135,180,225,270$, and $315^{\circ}$. In most instances, the top increment was less than $1.5 \mathrm{~m}$.

Using crown heights, azimuths and crown radius information, we chose random locations that fell within the crown to sample leaves for leaf area and biomass measurements. Depending on the size of the tree, we chose six to ten random samples. To avoid removing too much leafy biomass from the tree, for smaller trees, we chose a minimum of six samples randomly for leaf collection. The random points were located within the crown using a height pole, the tip of the height pole serving as the visual location of the random point. A $0.4 \mathrm{~m}^{3}$ cube constructed of PVC pipe was placed around the height pole, the tip of the height pole serving as the center of the cube. All whole or partial leaves that fell within the borders of the PVC cube were sampled by an arborist in an aerial lift.

All the leaves sampled from within the $0.4 \mathrm{~m}^{3}$ cube were weighed to determine the fresh weight $(\mathrm{g})$ for the sample. After weighing, the leaf area $\left(\mathrm{cm}^{2}\right)$ was then measured for each sample using the LICOR LI3100C Area Meter. If the sample had more than 400 leaves (arbitrarily chosen based on amount of time it takes to measure leaves), then 40 sample leaves were randomly selected from the sample. We calculated average leaf area using the 40 sample leaves. The total number of leaves for the sample was then multiplied by this average to determine the total leaf area for the sample. After leaf area measurements were determined, the leaf samples were dried for $24 \mathrm{~h}$ at $60{ }^{\circ} \mathrm{C}$. and measured for dry weight $(\mathrm{g})$. Estimates of total leaf area $\left(\mathrm{m}^{2}\right)$ and total leaf biomass $(\mathrm{g})$ per tree were determined by multiplying the mean leaf area and leaf biomass per $\mathrm{m}^{3}$ (obtained from the $0.4 \mathrm{~m}^{3}$ sample) by total crown volume.

Similar to Nowak (1996), we fit two regression models for predicting leaf area $\left(\mathrm{m}^{2}\right)$ and dry weight biomass $(\mathrm{g})$. The first model (hereafter referred to as Dbh model) used Dbh and average shading factor [SF; percent light intensity intercepted by foliated crowns; (McPherson, 1984; Nowak, 1996)] as independent variables and leaf area or biomass as dependent variable. Average shading factors for each tree species were taken from Nowak (1996). The second model (hereafter referred to as crown model) used variables describing the tree 
Table 1

Number of tree species in different diameter classes that were sampled to develop leaf area and leaf biomass models in Stevens Points, WI.

\begin{tabular}{|c|c|c|c|c|c|c|c|}
\hline \multirow[t]{2}{*}{ Species } & \multicolumn{6}{|c|}{ Diameter classes $(\mathrm{cm})$} & \multirow[t]{2}{*}{ Total } \\
\hline & $10-20$ & $20-30$ & $30-40$ & $40-50$ & $50-60$ & $>60$ & \\
\hline Ulmus americana L. (American elm) & 7 & 2 & 2 & 2 & & 1 & 14 \\
\hline Gleditsia triacanthos L.f. inermis (L.) C.K. Schneid. (Thornless common honeylocust) & 5 & 4 & 2 & 1 & 1 & 2 & 15 \\
\hline Acer platanoides L. (Norway maple) & 5 & 3 & 2 & 3 & 1 & & 14 \\
\hline Celtis occidentalis L. (Common hackberry) & 3 & 2 & 5 & 2 & 1 & 2 & 15 \\
\hline Fraxinus pennsylvanica Marshall (green ash) & 6 & 3 & 6 & 1 & & & 16 \\
\hline
\end{tabular}

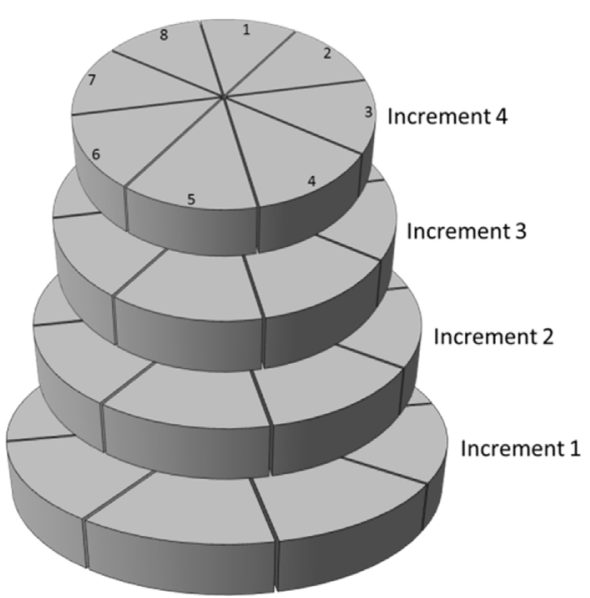

Fig. 2. Simplified pictorial representation of tree volume calculation.

crown such as crown height (H), average crown diameter (D), average shading factor, and outer surface area of the tree crown (C) as independent variables (Gacka-Grzesikjewicz, 1980; McPherson 1984; Nowak 1996), where $C$ is calculated as $\pi D(H+D) / 2$. The dependent variables, leaf area and biomass, were log transformed before fitting the models.

We used Akaike Information Criteria (AIC; Akaike, 1973) and significance of individual variables for selecting the most parsimonious model. Model fitness was assessed using R-squared, Adjusted Rsquared, Root Mean Square Error, and the regression between observed and predicted values for each model.

We used sixty-four observations (trees, fitting data) to fit the models and ten randomly selected observations (validation data) for model comparisons and validation (two trees per species). Validation data was not used in model fitting. Some observations identified as outliers were removed during the model fitting process. We used our models and Nowak (1996) models to predict leaf area and biomass of ten trees in the validation data and compared the predictions using Root mean square error (RMSE), Relative RMSE, Bias, and Relative Bias. These variables were calculated as:

RMSE $=\sqrt{\frac{\sum_{i=1}^{n}\left(y_{i}-\hat{y}_{i}\right)^{2}}{n}}$

Relative RMSE $=\frac{R M S E}{\bar{y}_{i}} \times 100$

Bias $=\frac{\sum_{i=1}^{n}\left(y_{i}-\hat{y}_{i}\right)}{n}$

Relative Bias $=\frac{\text { Bias }}{\overline{y_{i}}} \times 100$

where $y_{i}$ is the observed value, $\hat{y}_{i}$ is the predicted value and $\overline{y_{i}}$ is mean of observed values. We further tested the predictive accuracy of Nowak (1996) models only by predicting leaf area and biomass of 59 trees in
Table 2

Descriptive statistics of the variables used in model fitting.

\begin{tabular}{|c|c|c|c|c|}
\hline Attributes & Mean & Range & SE & $\begin{array}{l}\text { 95\% Confidence } \\
\text { Interval }\end{array}$ \\
\hline $\operatorname{Dbh}(\mathrm{cm})$ & 32.1 & $9.0-82.4$ & 2.04 & $28.0-36.2$ \\
\hline Height (m) & 11.1 & $6.3-20.7$ & 0.41 & $10.3-11.9$ \\
\hline $\begin{array}{l}\text { Average Crown } \\
\text { Diameter }(\mathrm{m})\end{array}$ & 8.9 & $3.9-19.6$ & 0.40 & $8.1-9.7$ \\
\hline $\begin{array}{l}\text { Crown Length } \\
\text { (m) }\end{array}$ & 7.6 & $3.6-14.6$ & 0.28 & $7.1-8.2$ \\
\hline Leaf Area $\left(\mathrm{m}^{2}\right)$ & 199.2 & $8.2-1683.2$ & 32.30 & $134.6-263.7$ \\
\hline $\begin{array}{c}\text { Leaf Dry Weight } \\
\text { Biomass }(\mathrm{g})\end{array}$ & 14692.6 & $698.6-127218.8$ & 2327.60 & $10041.4-19343.8$ \\
\hline
\end{tabular}

our model fitting data (5 trees in the current data set had Dbh's outside the range of Nowaks's model). Paired $t$-tests between observed and predicted values were used to assess the predictions. For comparative purposes, we back transformed all the predictions and corrected for bias due to logarithmic transformation by multiplying the back transformed value by $e^{\mathrm{MSE} / 2}$ (Bakersville 1972).

\section{Results and discussion}

Tree sizes ranged from $9.0 \mathrm{~cm}$ to $82.4 \mathrm{~cm}$ in Dbh (Table 2). There were only 8 trees with a Dbh $>50 \mathrm{~cm}$. Tree height ranged from 6.3 to $20.7 \mathrm{~m}$ (Table 2) and seven trees were greater than $15 \mathrm{~m}$ in height. Mean leaf area was $199.2 \mathrm{~m}^{2}$ and mean leaf biomass was $14.7 \mathrm{~kg}$ (Table 2).

\subsection{Model fitting}

In the Dbh model for leaf area (Eq. (1)), both Dbh and shading factor were significant predictors of leaf area. The model had higher Rsquared (0.64) value and lower RMSE (0.52) value than reported in Nowak (1996) (Table 3). Regression between observed and predicted values also had higher R-squared and higher slope coefficient (Fig. 3a).

Ln (leafarea $)=b_{0}+b_{1} d b h+b_{2} S F$

where Dbh is the diameter at breast height and SF is shading factor.

In the current Dbh model for leaf biomass (Eq. (2)), only Dbh was the significant predictor. Similar to Nowak (1996), shading factor was not a significant predictor of leaf biomass. The current model had a higher R-squared (0.69) and lower RMSE (0.57) than similar model in Nowak (1996) (Table 3). For the current model, there is a significant agreement between observed and predicted values as indicated by higher R-squared and higher slope coefficient (Fig. 3b).

Ln (dry weight biomass $)=b_{0}+b_{1} d b h$

where variables are as for Eq. (1).

In the current crown model (Eq. (3)) for leaf area, the significant predictors of leaf area were crown height, average crown diameter, shading factor, and outer surface area of the crown. This result is similar to Nowak (1996), however the current model had lower Rsquared value and higher RMSE than Nowak (1996) (Table 4). There 
Table 3

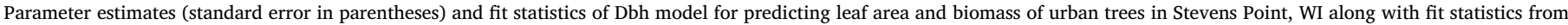
Nowak (1996).

\begin{tabular}{|c|c|c|c|c|c|c|c|c|c|}
\hline Models & $\mathrm{N}$ & $\begin{array}{l}\text { Dependent } \\
\text { variable }\end{array}$ & $\mathrm{b}_{0}$ & $b_{1}$ & $\mathrm{~b}_{2}$ & $\mathrm{R}^{2}$ & RMSE & $\mathrm{R}^{2}$ Nowak & $\begin{array}{l}\text { RMSE } \\
\text { Nowak }\end{array}$ \\
\hline Dbh & 61 & Leaf area & $\begin{array}{l}-0.06 \\
(0.687)\end{array}$ & $\begin{array}{l}0.05 \\
(0.004)\end{array}$ & $\begin{array}{l}3.97 \\
(0.82)\end{array}$ & 0.74 & 0.52 & 0.64 & 0.58 \\
\hline Dbh & 61 & Dry Weight biomass & $\begin{array}{l}7.47 \\
(0.16)\end{array}$ & $\begin{array}{l}0.05 \\
(0.005)\end{array}$ & $\mathrm{ns}^{\mathrm{a}}$ & 0.69 & 0.57 & 0.54 & 0.60 \\
\hline
\end{tabular}

${ }^{\mathrm{a}}$ ns is not significant.

was significant agreement between observed and the predicted value for the current crown model as indicated by the higher R-squared value (Fig. 3c), which is similar to Dbh model for leaf area described above.

Ln (leafarea $)=b_{0}+b_{1} * H+b_{2} * D+b_{3} * S F+b_{4} * C$

where $\mathrm{H}$ is the crown height, $\mathrm{D}$ is the average crown diameter, and $\mathrm{C}$ is the outer surface area of the crown.

In the current crown models, both leaf area and dry weight biomass had similar predictors (Eqs. (3) and (4)). The current crown model for dry weight biomass had a lower R-squared value and RMSE than Nowak (1996) (Table 4). There was agreement between observed and predicted values for dry weight biomass as indicated by R-squared value (Fig. 3d).
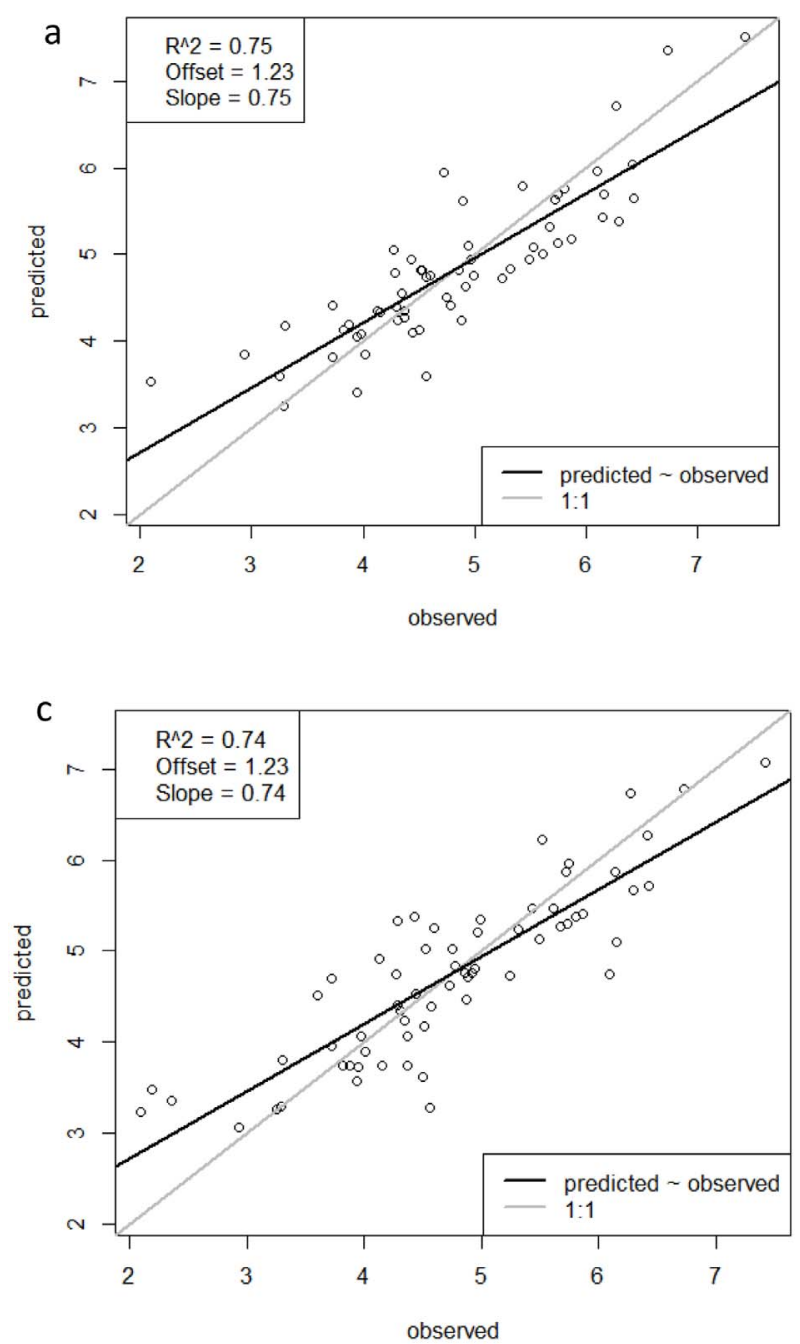

Ln (dry weight biomass $)=b_{0}+b_{1} * H+b_{2} * D+b_{3} * S F+b_{4} * C$

With one exception, the signs for the coefficients in current models were similar to those reported by Nowak (1996). The lone exception was the negative sign for the intercept in the leaf area Dbh model (Table 3). Based on Nowak's work, we expected the crown model would better fit the data than Dbh model. However, current Dbh models had better R-squared and lower RMSE values compared to the crown models (Tables 3 and 4).

\subsection{Model comparison and validation}

We estimated and compared leaf area and biomass using the current models and models from Nowak (1996) using the validation data set
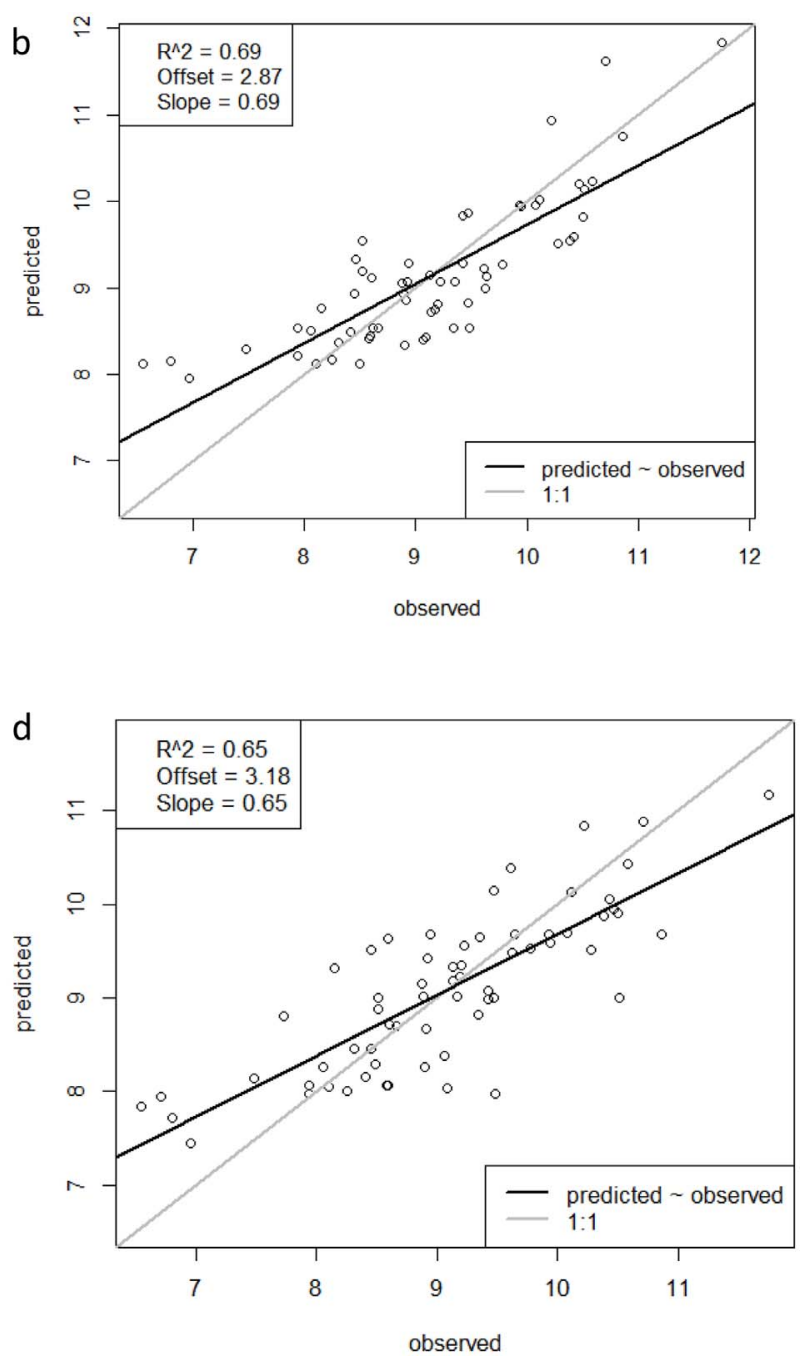

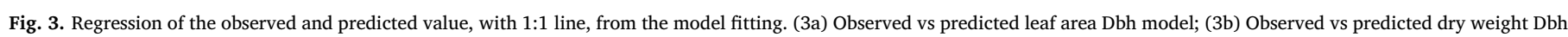
model; (3c) Observed vs predicted leaf area crown model; (3d) Observed vs predicted dry weight crown model. 
Table 4

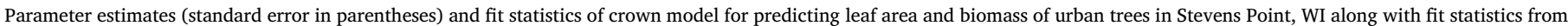
Nowak (1996).

\begin{tabular}{|c|c|c|c|c|c|c|c|c|c|c|c|}
\hline Models & $\mathrm{N}$ & Dependent variable & $\mathrm{b}_{0}$ & $\mathrm{~b}_{1}$ & $\mathrm{~b}_{2}$ & $\mathrm{~b}_{3}$ & $\mathrm{~b}_{4}$ & $\mathrm{R}^{2}$ & RMSE & $\begin{array}{l}\mathrm{R}^{2} \\
\text { Nowak }\end{array}$ & $\begin{array}{l}\text { RMSE } \\
\text { Nowak }\end{array}$ \\
\hline Crown & 64 & Leaf area & $\begin{array}{l}-3.21 \\
(1.11)\end{array}$ & $\begin{array}{l}0.16 \\
(0.053)\end{array}$ & $\begin{array}{l}0.43 \\
(0.105)\end{array}$ & $\begin{array}{l}4.80 \\
(1.001)\end{array}$ & $\begin{array}{l}-0.004 \\
(0.002)\end{array}$ & 0.72 & 0.57 & 0.91 & 0.48 \\
\hline Crown & 64 & $\begin{array}{l}\text { Dry Weight } \\
\text { biomass }\end{array}$ & $\begin{array}{l}3.03 \\
(1.24)\end{array}$ & $\begin{array}{l}0.15 \\
(0.059)\end{array}$ & $\begin{array}{l}0.41 \\
(0.117)\end{array}$ & $\begin{array}{l}2.83 \\
(1.12)\end{array}$ & $\begin{array}{l}-0.004 \\
(0.002)\end{array}$ & 0.63 & 0.64 & 0.92 & 0.46 \\
\hline
\end{tabular}

Table 5

Bias and RMSE of estimated leaf area and biomass of validation sample using current models and Nowak (1996).

\begin{tabular}{|c|c|c|c|c|c|c|c|c|}
\hline Models & $\begin{array}{l}\text { Bias } \\
\text { Current } \\
\text { model }\end{array}$ & $\begin{array}{l}\text { Bias Nowak } \\
\text { (1996) }\end{array}$ & $\begin{array}{l}\text { Relative Bias Current } \\
\text { model (\% of mean) }\end{array}$ & $\begin{array}{l}\text { Relative Bias } \\
\text { Nowak (1996) } \\
\text { (\% of mean) }\end{array}$ & $\begin{array}{l}\text { RMSE } \\
\text { Current } \\
\text { model }\end{array}$ & $\begin{array}{l}\text { RMSE Nowak } \\
\text { (1996) }\end{array}$ & $\begin{array}{l}\text { Relative } \\
\text { RMSE } \\
\text { Current } \\
\text { model } \\
\text { (\% of mean) }\end{array}$ & $\begin{array}{l}\text { Relative RMSE Nowak } \\
\text { (1996) (\% of mean) }\end{array}$ \\
\hline $\begin{array}{l}\text { Dbh model for leaf area } \\
\qquad\left(\mathrm{m}^{2}\right)\end{array}$ & -6.6 & -113 & -6 & -106 & 65 & 185 & 49 & 138 \\
\hline $\begin{array}{l}\text { Crown model for leaf } \\
\text { area }\left(\mathrm{m}^{2}\right)\end{array}$ & -6.5 & -127 & -5.8 & -115.7 & 68 & 183 & 62 & 166 \\
\hline $\begin{array}{l}\text { Dbh model for dry } \\
\text { weight }(g)\end{array}$ & -8105 & -69310 & -98 & -839 & 4078 & 11443 & 59 & 168 \\
\hline $\begin{array}{l}\text { Crown model for } \\
\text { dry weight }(\mathrm{g})\end{array}$ & -728 & -13401 & -8.8 & -162.3 & 5141 & 21363 & 62.3 & 258.8 \\
\hline
\end{tabular}

(10 trees, 5 species). Both models tended to overestimate leaf area and leaf biomass (Table 5). On average, current Dbh and crown models over estimated leaf area by $6.6 \mathrm{~m}^{2}$ ( $6 \%$ of the observed mean leaf area) and $6.5 \mathrm{~m}^{2}(5.8 \%$ of the mean) respectively. However, the Nowak (1996) Dbh and crown models overestimated leaf area on average by $113 \mathrm{~m}^{2}$ (106\% of the mean) and $127 \mathrm{~m}^{2}(115 \%$ of the mean), respectively (Table 5). Similarly, the relative root mean square error for leaf area predictions using the Nowak (1996) models were more than $200 \%$ higher than the current models (Table 5).

On average, the current Dbh and crown models over predicted leaf dry weight by $8 \mathrm{~kg}$ ( $98 \%$ of the mean observed dry weight) and $0.7 \mathrm{~kg}$ (8.8\% of the mean), respectively. The Nowak (1996) Dbh and crown models over predicted dry weight by $69 \mathrm{~kg}$ (839\% of the mean) and $13 \mathrm{~kg}$ ( $162.3 \%$ of the mean), respectively (Table 5). As with leaf area, the relative root mean square error for biomass predictions from Nowak (1996) were more than 200\% higher than the current models (Table 5).

Both Nowak's model and our model predicted leaf area and biomass adequately for smaller trees (Fig. 4a-d ). Prediction errors for leaf area and biomass for larger trees with higher Dbh, crown length, average crown diameter, and crown surface area were also higher (see supplementary material Figs. S1-S3). The reasons for this are the presence of a large number of samples in the smaller size class and the error associated with estimating observed leaf area and biomass for larger trees. In our data, larger trees $(>40 \mathrm{~cm}$ ) had higher amount of variation in observed leaf area and biomass than smaller trees. Antonio et al. (2007) reported higher prediction error either for very smaller size classes or for bigger trees while using their leaf biomass equation in Eucalyptus globulus. Our models did much better in predicting leaf area and biomass than Nowak's model overall (Fig. 4a-d).

Paired $t$-tests comparing observed vs predicted values (at $\alpha=0.05$ ) indicated the current crown model predictions for leaf area $(P=0.78)$ and leaf biomass $(P=0.67)$ did not significantly differ from the observed values. Conversely, the Nowak (1996) model predictions were significantly different from the observed for both leaf area $(P=0.018)$ and dry weight biomass $(P=0.03)$. Similarly, the current Dbh model predictions were not significantly different from the observed values for leaf area $(P=0.76)$ and leaf dry weight biomass ( $P=0.55$ ). Predictions using the Nowak (1996) models were, however, significantly different than observed values for both leaf area
$(P=0.04)$ and leaf dry weight biomass $(P=0.04)$.

Nowak's model was developed using data from Chicago, which is warmer and wetter than Stevens Point. Due to warmer and wetter climate, similar sized tree of the same species might have bigger leaves in Chicago compared to Stevens Point; therefore, using models from Chicago on trees of Stevens Point could have overestimated leaf area and biomass. This explanation is supported by studies indicating the effect of environment on leaf morphology; for example, two Australian tree species growing on drier and nutrient poor soils had lower specific leaf area (SLA; Witkowski and Lamont, 1991) compared to wetter sites. In addition, Meziane and Shipley (1999) reported that the decrease in irradiance increased specific leaf area (SLA) of herbaceous plants, however, the effect varied at different nutrient levels. Furthermore, sun leaves are thicker than shade leaves due to greater palisade parenchyma, spongy parenchyma, and epidermal tissue (Evans, 1999). In addition to morphological plasticity among individuals of the same species due to environmental stress (Gratani, 2014), genetic differences between individuals could be another reason for overestimation.

The current Dbh and crown models possessed similar fit statistics for leaf area (Tables 3 and 4). As a result, the predicted values for leaf area using the independent data set were comparable under both models (Table 4). Although the fit statistics were better for the current Dbh model (Tables 2 and 3), the current crown model adequately predicted leaf dry weight biomass (Table 5). Consequently, we did not find evidence that the current crown model is better than current Dbh model. Taking into consideration the amount of time to gather the crown data, our results suggest the Dbh model is a reliable estimator of leaf area and biomass. The reason for inferior performance of the crown models could be due to not including predictor variables that account for leaf size and leaf density within the crown. Also, pruning activities affect the relationship between leaf area and biomass and crown parameters. Nowak (1996) also mentioned that their equations overestimate leaf area and biomass for trees exhibiting leaf loss due to insect and pruning; they further suggested that future research is needed in understanding how area and biomass changes due to pruning leaf. Similarly, Peper et al. (2001) mentioned pruning as a highly variable social factor that affects tree size and leaf area; they cautioned applying their leaf area equations to similar climatic zones unless pruning 

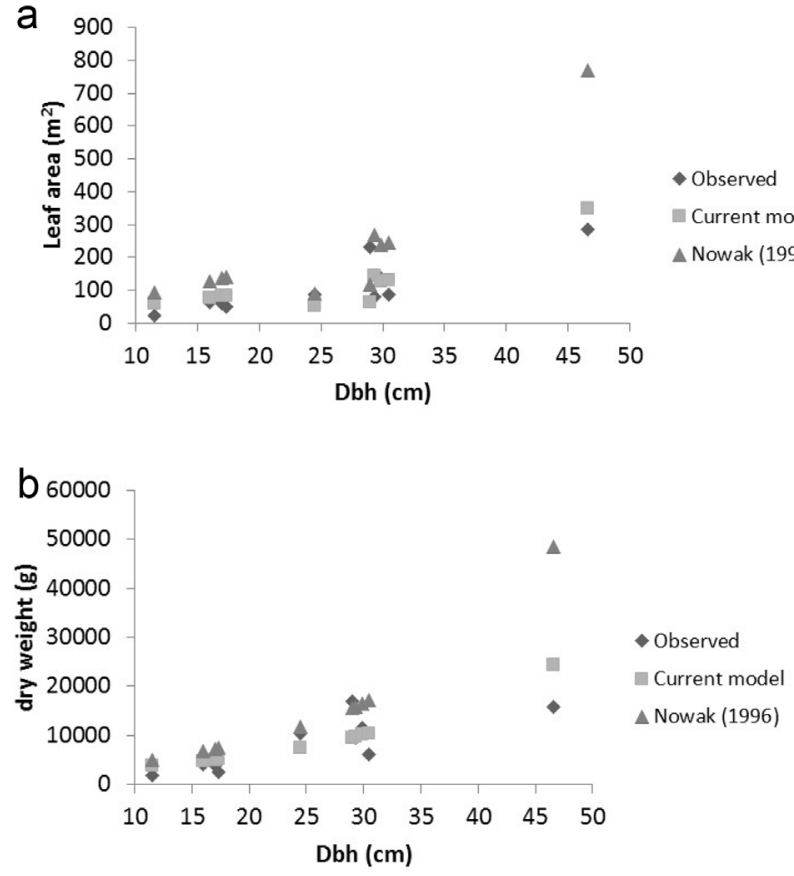
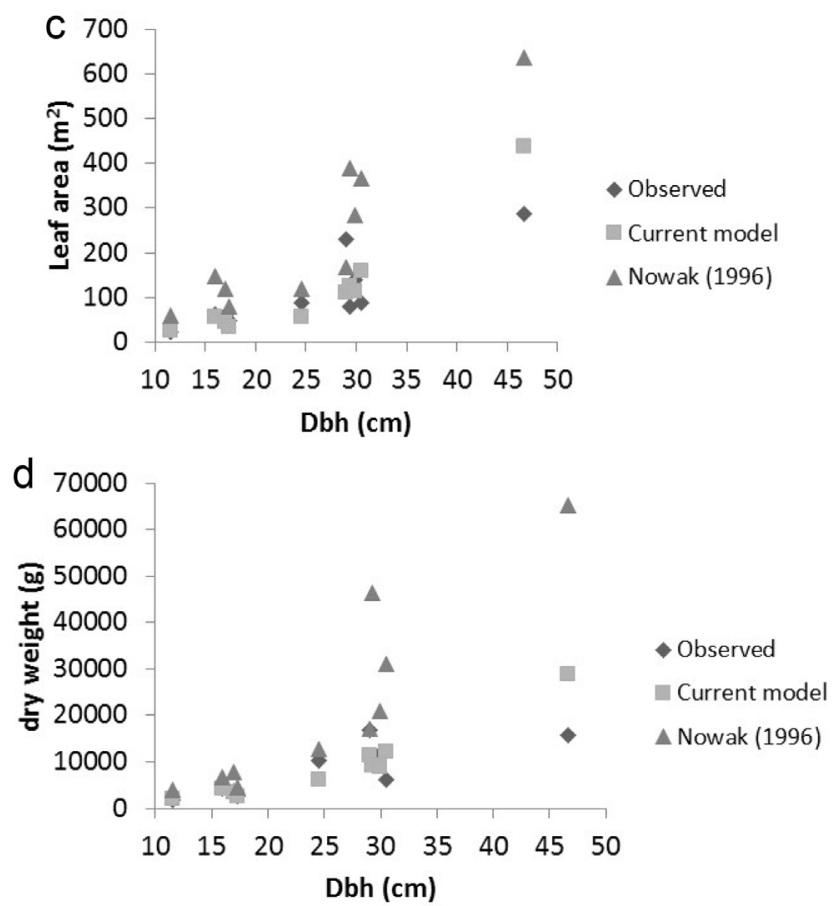

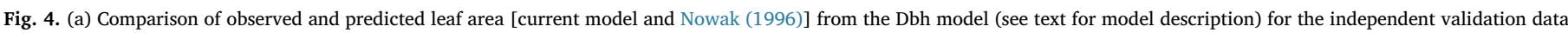

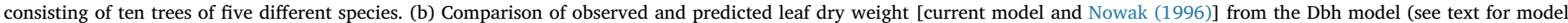

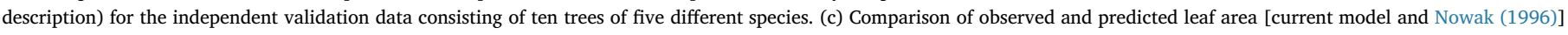

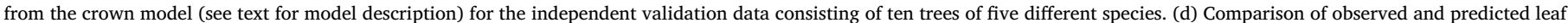

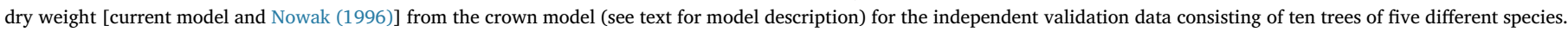

information that describes the amount and density of crown reductions is available.

We also tested predictive accuracy of Nowak (1996) models utilizing the data to fit our models. The comparison of observed and predicted values indicated that Nowak (1996) models over estimated both leaf area and biomass (Table 6). Relative bias for leaf area from Nowak's Dbh model was $92 \%$ and for the crown model was $99 \%$. (Table 6). Similarly, relative bias for dry weight from the Dbh model was $81 \%$ and for the crown model was $125 \%$. In addition, relative RMSE was greater than $100 \%$ for all the four models (Table 6). Although, the crown models had better fit statistics in Nowak (1996), the predictions from the Dbh model were much better than the predictions from the crown model (Table 6). The reduced predictive ability of the crown model suggests either the variables used in the crown model do not provide additional information, about leaf area and biomass and/or, maintenance strategies or rotation lengths differed markedly between the two communities from which the data to fit the models were derived. More specifically, differences in the amount of living biomass removed during pruning events or the number of pruning events prior to model development could have contributed to

Table 6

Bias and RMSE of estimated leaf area and biomass, using Nowak 1996 models, of 59 trees in the model fit data.

\begin{tabular}{lllll}
\hline Models & Bias & Relative Bias (\%) & RMSE & $\begin{array}{l}\text { Relative } \\
\text { RMSE } \\
(\%)\end{array}$ \\
\hline $\begin{array}{c}\text { Dbh model for leaf area } \\
\left(\mathrm{m}^{2}\right)\end{array}$ & -142 & -92 & 218 & 141 \\
$\begin{array}{c}\text { Crown model for leaf area }\left(\mathrm{m}^{2}\right) \\
\text { Dbh model for dry weight } \\
\quad(\mathrm{gm})\end{array}$ & -153 & -99 & 199 & 129 \\
$\begin{array}{c}\text { Crown model for dry weight } \\
(\mathrm{gm})\end{array}$ & -14395 & -125 & 14954 & 130 \\
\hline
\end{tabular}

the lack of predictive power associated with the crown model.

The current Dbh and crown models did not include all the variables that might affect leaf area and biomass in a tree, for example, we did not include variables that represent leaf density and effect of cultural practices in our models. Furthermore, data from five different species were combined to develop a single model. Due to this, there were errors associated with predictions from the current models, but they did a better job of predicting leaf area and leaf dry weight than Nowak (1996) models. Bias and RMSE from Nowak (1996) models were much higher (Tables 4 and 5). Peper and McPherson (2003) also reported that the crown model from Nowak (1996) overestimated leaf area for two species in northern California. Dobbs et al. (2011) also reported that the Dbh model from Nowak (1996) overestimated leaf area relative to a locally developed equation in Santiago, Chile. This result has consequences for the use of i-Tree model for estimating and valuing ecosystem services without changing the underlying equation. The predicted leaf area and biomass estimates will ultimately affect the extent and value of ecosystem services.

\section{Conclusions}

Our data indicated that the local models (developed in current study) better predicted leaf area and biomass than general models (Nowak, 1996). Our Dbh models were better than our crown models. The prediction errors from Nowak's crown models for 59 of the sample trees were higher than Nowak's Dbh models. Given the time it takes to collect crown data, the Dbh model seemed better in predicting leaf area and biomass. Our results showed that predictions from locally developed leaf area and biomass models were much closer to the observed value than general equation of Nowak (1996). For example, locally developed leaf area models (current models) on average over predicted leaf area by $5.8 \%-6 \%$ of the observed mean whereas Nowak (1996) general models over predicted leaf area by $106 \%-115 \%$. Additionally, the predictive models in this study were more reliable on small trees, suggesting a need to intensify the sampling within the crowns of larger 
trees. Lastly, future research should identify the pruning rotation lengths for the communities from which the model was developed.

The results highlight the importance of locally derived equations to estimate the value of ecosystem services and will encourage researchers/managers to acknowledge the uncertainty of estimates resulting from the application of general equations.

\section{Acknowledgements}

We would like to thank Wisconsin Department of Natural Resources Urban \& Community Forestry Program, USDA Forest Service (McIntireStennis Grant), and the University of Wisconsin-Stevens Point Office of Research and Sponsored Program (UPDC New Faculty Grant) for funding this study. We would also like to thank City of Stevens Point Forestry Department, especially City Forester Todd Ernster, for providing data and logistical help (air lift). Finally, a big thank you to First Choice Tree Care, Inc. for providing the aerial lift truck and an operator.

\section{References}

Akaike, H., 1973. Information theory and an extension of the maximum likelihood principle. In: Petrov, B.N., Caski, F. (Eds.), Proceeding of the Second International Symposium on Information Theory. Academiai Kiado, Budapest, pp. 267-281.

Antonio, N., Tome, M., Tome, J., Soares, P., Fontes, L., 2007. Effect of tree, stand, and site variables on the allometry of Eucalyptus globulus tree biomass. Can. J. For. Res. 37, 895-906.

Bakersville, G.L., 1972. Use of logarithmic regression in the estimation of plant biomass. Can. J. For. Res. 2, 49-53.

Close, R.E., Nguyen, P.V., Kielbaso, J.J., 1996a. Urban vs. natural sugar maple growth: I: stress symptoms and phenology in relation to site characteristics. J. Arboric. 22, 144-150.

Close, R.E., Kielbaso, J.J., Nguyen, P.V., Schutzki, R.E., 1996b. Urban vs. natural sugar maple growth: II: water relations. J. Arboric. 22, 187-192.

Dobbs, C., Hernández, J., Escobedo, F., 2011. Above ground biomass and leaf area models based on a non-destructive method for urban trees of two communes in Central Chile. Bosque 32 (3), 287-296.

Dwyer, J.F., McPherson, E.G., Schroeder, H.W., Rowntree, R.A., 1992. Assessing the benefits and costs of the urban forest. J. Arboric. 18, 227.

Escobedo, F., Varela, S., Zhao, M., Wagner, J.E, Zipperer, W., 2010. Analyzing the efficacy of subtropical urban forests in off-setting carbon emissions from cities. Environ. Sci. Policy 13, 362-372.

Evans, J.R., 1999. Leaf anatomy enables more equal access to light and $\mathrm{CO}_{2}$ between choloroplasts. New Phytol. 143, 93-104.

Gacka-Grzesikjewicz, E., 1980. Assimilation surface of urban green areas. Ekol. Polsa 28 (4), 493-523.

Gratani, L., 2014. Plant phenotypic plasticity in response to environmental factors. Adv. Bot. 2014, 1-17.

Lines, E.R., Zavala, M.A., Purves, D.W., Coomes, D.A., 2012. Predictable changes in aboveground allometry of trees along gradients of temperature, aridity and competition. Global Ecol. Biogeogr. 21, 1017-1028.

McHale, M.R., Burke, C., Lefsky, A., Peper, J., McPherson, G., 2009. Urban forest biomass estimates: is it important to use allometric relationships developed specifically for urban trees? Urban Ecosyst. 12 (1), 95-113.

McPherson, E.G., 1984. Planting design for solar control. In: McPherson, E.G. (Ed.), Energy-Conserving Site Design. American Society of Landscape Architecture, Washington, DC, pp. 141-164.

Meziane, D., Shipley, B., 1999. Interacting determinants of specific leaf area in 22 herbaceous species: effects of irradiance and nutrient availability. Plant Cell Environ. 22, 447-459.

Miller, R.W., Hauer, R.J., Werner, L.P., 2015. Urban Forestry Planning and Managing: Urban Greenspaces, 3rd edition. Waveland Press, Long Grove, IL.

Nowak, D.J., Crane, D.E., 2002. Carbon storage and sequestration by urban trees in the USA. Environ. Pollut. 116, 381-389.

Nowak, D.J., Dwyer, J.F., 2007. Understanding the benefits and costs of urban forest ecosystems. In: Kusher, J.E. (Ed.), Urban and Community Forestry in the Northeast. Springer, Netherlands, pp. 25-46.

Nowak, D.J., Walton, J.T., 2005. Projected urban growth (2000-2050) and its estimated impact on the US forest resource. J. For. 103 (8), 383-389.

Nowak, D.J., Crane, D.E., Stevens, J.C., Hoehn, R.E., Walton, J.T., Bond, J., 2008. A ground-based method of assessing urban forest structure and ecosystem services. Arboric. Urban For. 34 (6), 347-358.

Nowak, D.J., 1996. Estimating leaf area and leaf biomass of open-grown deciduous urban trees. For. Sci. 42 (4), 504-507.

Nowak, D.J., 2015. The Science and Future of i-Tree. May 2015 webinar. Accessed online August 25, $2016<$ http://www.itreetools.org/resources/presentations.php > .

Pallardy, S.G., 2008. Physiology of Woody Plants. Academic Press.

Peper, P.J., McPherson, E.G., 2003. Evaluation of four methods for estimating leaf area of isolated trees. Urban For. Urban Green. 2 (1), 19-29.

Peper, P.J., McPherson, E.G., Mori, S.M., 2001. Equation for predicting diameter, height, crown width, and leaf area of San Joaquin valley street trees. J. Arboric. 27, 306-317.

Rhoades, R.W., Stipes, R.J., 1999. Growth of trees on the Virginia Tech campus in response to various factors. J. Arboric. 25, 211-217.

Russo, A.R., Escobedo, F.J., Timilsina, N., Schmitt, A.O., Varela, S., Zerbe, S., 2014. Assessing urban tree carbon storage and sequestration in Bolzano, Italy. Int. J. Biodivers. Sci. Ecosyst. Serv. Manage. 10, 54-57.

Rust, S., 2013. Analysis of regional variation of height growth and slenderness in populations of six urban tree species using a quantile regression. Urban For. Urban Green. 13, 336-343.

Rydin, A., Bleahu, A., Davies, M., Davila, J.D., Friel, S., De Grandis, G., Groce, N., Hallal, P.C., Hamilton, I., Howden-Chapman, P., 2012. Shaping cities for health: complexity and the planning of urban environments in the 21st century. Lancet 379, 2079-2108.

Scharenbroch, B.C., Catania, M., 2012. Soil quality attributes as indicators of urban tree performance. Arboric. Urban For. 38 (5), 214-228.

Seto, K.C., Güneralp, B., Hutyra, L.R., 2012. Global forecasts of urban expansion to 2030 and direct impacts on biodiversity and carbon pools. Proc. Natl. Acad. Sci. 109 (40), 16083-16088.

Timilsina, N., Staudhammer, C.L., Escobedo, F.J., Lawrence, A., 2014. Tree wood waste biomass yield and cabon storage changes in an urban forest. Land Use Urban Plann. 127, 18-27.

United Nations, 2010. World Urbanization Prospects. The 2010 Revision. United Nations, New York.

Witkowski, E.T.F., Lamont, B., 1991. Leaf specific mass confounds leaf density and thickhness. Oecologica 88, 486-493.

Wolf, K.L., 2003. Public reponse to the urban forest in inner-city business districts. J. Arboric. 29 (3), 117-126.

Zhao, M., Kong, Z., Escobedo, F.J., Gao, J., 2010. Impacts of urban forests on offsetting carbon emissions from industrial energy use in Hangzhou, China. J. Environ. Manage. 91, 807-813. 